\title{
BAKTI DAN PENGENALAN SITUS CANDI KALICILIK PADA SISWA SD 1 CANDIREJO PONGGOK BLITAR
}

\author{
Wahyu Djoko Sulistyo*, Dera Trisna F, Diky Febriant, M. Davit E, Muhtia Wahyu Afi, Nurul \\ Hidayati, Wisnu Luhung P, Yuli Fitriani, \\ wahyu.djoko.fis@um.ac.id
}

Jurusan Sejarah, Fakultas IImu Sosial, Universitas Negeri Malang

Diterima 16 Mei 2018, dipublikasikan 31 Oktober 2019

\begin{abstract}
Abstrak: Kegiatan pengabdian kepada masyarakat dalam praksis social ini adalah bakti dan pengenalan situs Candi Kalicilik Blitar. Kegiatan ini bertujuan untuk mengenalkan keberadaan situs sejarah Candi Kalicilik kepada masyarakat sekitar. Target sasaran dalam kegiatan ini yaitu siswa SD Candirejo 1 Ponggok Blitar. Sekolah ini dijadikan objek karena posisi sekolah yang terletak tidak jauh dari situs namun banyak siswanya yang tidak mengetahui adanya candi tersebut. Pengenalan terhadap situs ini menjadi penting karena untuk melestarikan situs sejarah diawali dengan kegiatan mengenali. Pelaksanaan pengabdian dalam kegiatan praksis ini melalui tiga tahap yaitu, persiapan pelaksanaan dan evaluasi. Kegiatan observasi dan koordianasi dengan pihak sekolah maupun pengelola candi dilakukan pada taha persiapan. Pada tahap pelaksanaan bakti dan pengenalan candi dilakukan dengan membersihkan lingkungan sekitar situs candi dan mengenalkan sejarah situs kepada siswa SD 1 Candirejo. Selama proses pengenalan berlangsung siswa antusias untuk mengikuti kegiatan, dan diakhiri dengan kegiatan evaluasi. Hasil bakti dan pengenalan situs candi menunjukkan bahwa beberapa siswa SD 1 candirejo sudah mengenal situs candi Kalicilik, mereka tahu jika candi kalicik merupakan peninggalan masa kerajaan Majapahit. Akan tetapi masih ada beberapa siswa yang tidak tahu dan belum pernah ke candi Kalicilik. Dengan pengenalan situs candi Kalicilik dapat menambah wawasan pengetahuan warga setempat khususnya generasi muda agar peduli serta menjaga peninggalan-peninggalan penting yang ada di daerah sekitarnya.
\end{abstract}

Kata Kunci: Bakti, Pengenalan, Candi Kalicilik,

\section{PENDAHULUAN}

Seiring dengan perkembangan zaman situs-situs sejarah yang ada di indonesia kurang mendapat perhatian. Hal ini terjadi karena kurangnya kesadaran masyarakat khususnya yang tinggal di dekat situs tersebut untuk melestarikan dan merawat. Pada era modern seperti saat ini sebagai generasi penerus perlu untuk menjaga dan memperkenalkan situs-situs sejarah yang belum banyak dikenal oleh kalangan masyarakat. Situs sejarah merupakan warisan yang harus kita jaga karena dalam situs sejarah memiliki makna dan pesan tersendiri, maksudnya dibuatnya peninggalan tersebut oleh orang terdahulu pasti memiliki tujuan yang ingin disampaikan pada generasi selanjutnya. Oleh karena itu perlunya upaya untuk menyadarkan masyarakat terhadap pelestariaan cagar budaya (Arafah, 2003; Karmadi, 2007; Wibowo, 2014)

Menurut sedyawati dalam (Wahyudi, 2014:138), candi merupakan suatu kebudayaan yang bersifat bendawi yang didalamnya terdapat nilai kebudayaan penting untuk disampaikan, candi tidak hanya digunakan oleh masyarakat sebagai tempat ibadah tetapi juga sebagai istana, pemandian atau petirtaan, dan gapura. Banyak bentuk peninggalan sejarah masa kerajaan Hindhu-Budda yang berwujud candi, khususnya di Jawa (Sedyawati et al., 2013; Wendoris, 2008). Salah satu situs sejarah berupa candi yang perlu mendapatkan perhatian khusus di daerah Blitar adalah candi Kalicilik. Candi ini merupakan salah satu situs peninggalan bersejarah yang terletak di Dusun Candirejo, Desa Candirejo, Kecamatan Ponggok, Kabupaten Blitar. Candi Kalicilik merupakan salah satu peninggalan pada masa kerajaan Majapahit, candi tersebut masih belum banyak dikenal oleh masyarakat luas khususnya masyarakat Blitar sendiri (Campbell, 2002). Kondisi candi yang terletak tidak terlalu jauh dengan pemukiman warga namun banyak warga khususnya para generasi muda 
yang tidak mengenal bahkan tidak peduli dengan keberadaanya. Oleh karena itu perlu diadakanya suatu kegiatan untuk mengenalkan tentang keberadaan situs candi kalicilik dan sejarahnya kepada warga sekitar khususnya para anak-anak sebagai generasi penerus. Kegiatan bakti candi ini dimulai dengan membersihkan, membuat dan memasang papan informasi di area candi, selanjutnya mengenalkan situs candi kepada siswa SD terdekat.

Pengenalan candi Kalicilik terhadap siswa dimaksudkan untuk memberi pengetahuan mengenai situs peninggalan sejarah dan pentingnya menjaga serta merawatnya. Pengenalan situs sejarah sejak dini sangat dibutuhkan untuk menanamkan sikap kepedulian terhadap situs yang tidak terurus. Seperti yang kita tahu sebagian besar orang tidak mengetahui maksud dibangunnya sebuah candi. Hal ini dapat dibuktikan saat kita berkunjung ke situs-situs peninggalan sejarah banyak kita jumpai sekelompok orang yang melakukan selfie, jadi tujuan utama mereka bukan untuk mengeksplor sejarah situs tersebut melainkan untuk mendapatkan hasil foto yang bagus. Selain itu beberapa pengunjung yang datang di tempat situs biasanya membuang sampah disembarang tempat, hal tersebut menjadikan situs menjadi kotor dan terlihat tidak terurus dan tidak menarik lagi untuk dikunjungi. Dengan dilaksanakannya bakti dan pengenalan situs candi cilik baik untuk masyarakat dan dunia pendidikan diharapkan bisa menjaga dan mengenal candi tersebut lebih mendalam. Mereka dapat mengerti apa yang harus dilakukan untuk melindungi situs-situs sejarah agar generasi penerus berikutnya dapat melihat, mengenal, dan menikmati peninggalan tersebut sebagai sesuatu yang memiliki nilai historis. Ini merupakan salah satu bentuk dari upaya untuk memperkenalkan keberadaan candi selain dikemas dalam berbagai bentuk dan kegiatan seperti bahan ajar, batik dan lainya (Maslahah \& Rofiah, 2019; Nafi'ah, Utami, Sulistyo, Mahmud, \& Minarti, 2019). Bagi tim pengabdian, kegiatan ini dapat menumbuhkan rasa kepedulian dan kepekaan terhadap suatu kondisi dimasyarakat yang perlu dibenahi (Sulistyo, 2019). Oleh karena itu, dalam artikel ini akan membahas beberapa topik mengenai pentingnya melestarikan situs sejarah melalui bakti dan pengenalan candi kepada masyarakat sekitar yaitu siswa SD 1 Candirejo ponggok Blitar. Lebih lanjut artikel ini akan menjelaskan (1). Implementasi kegiatan bakti dan pengenalan candi Kalicilik (kendala yang dihadapi dan dampak, upaya keberlanjutan), (2). Seberapa jauh masyarakat sekitar mengenal situs Candi Kalicilik, (3). Hasil capaian yang didapat.

\section{METODE}

Rangkaian kegiatan dapat terlaksana dengan baik jika direncanakan dengan baik dan strategi yang tepat, terlebih lagi dalam pengabdian masyarakat ini peneliti berpartisipasi langsung dengan masyarakat (Mikkelsen, 2011). Secara garis besar metode pelaksanaan kegiatan dapat dibagi menjadi 3 tahap yaitu bagian persiapan, pelaksanaan, dan bagian evaluasi akhir. Berikut ini merupakan perincian dari tahapan-tahapan tersebut: (1) Tahap Persiapan, persiapan tahap pertama adalah observasi dan perizinan. Kegiatan observasi menjadi penentu awal dalam kegiatan penelitian (Arikunto, 2006; Sukmadinata, 2017). Dalam hal ini perizinan diajukan terhadap pihak sekolah dan candi yang akan dijadikan lokasi penyelenggaraan kegiatan. Setelah mendapat izin, maka hal yang dilakukan selanjuatnya adalah mempersiapkan segala alat dan bahan yang diperlukan pada hari penyelenggaraan kegiatan. Alat dan bahan tersebut yaitu alat-alat kebersihan yang digunakan untuk bakti candi, banner, hadiah untuk siswa dan konsumsi; (2) Tahap pelaksanaan, tahap pelaksanaan diilakukan selama 2 hari yaitu pada tanggal 14 Maret dan 22 maret 2019. Setelah persiapan perizinan dan persiapan bahan baku selesai, tahap ini merupakan tahap inti dari serangkaian persiapan panjang panitia. Yaitu kegiatan bakti candi pada hari pertama dan pengenalan situs Candi Kalicilik kepada siswa SD Candirejo 1; (3) Tahap evaluasi, tahap evaluasi dilakukan di hari kedua yaitu pada siswa SD Candirejo 1 setelah pengenalan situs Candi. Evaluasi dilakukan dengan game, karena dengan model evaluasi bentuk game akan lebih menarik bagi siswa (Chowanda \& Prasetio, 2012). Game tersebut berisi pertanyaan-pertanyaan mengenai penjelasan dari kelompok.

\section{HASIL DAN PEMBAHASAN}

Di era modern ini sulit untuk menyadarkan pentingnya situs sejarah khususnya bagi generasi muda. Kesadaran sejarah yang dimiliki khususnya para generasi muda masih perlu untuk 
ditingkatkan lagi ke level yang lebih tinggi (Vubo, 2003). Banyak anak-anak muda yang tidak peduli terhadap peninggalan nenek moyangnya, kadang mereka masih belum mengetahui bahkan mengenal peninggalan situs sejarah yang ada disekitarnya (Agustin, 2011). Sering kita jumpai beberapa peninggalan situs sejarah tidak dirawat, beberapa diantaranya dicoret-coret. Petingnya pelestarian situs sejarah tidak hanya dipandang dari segi keindahan arsitekturnya, namun nilai historis yang terkandung di dalamnya merupakan penghubung masa lalu degan masa sekarang sekaligus menjadi gambaran untuk masa yang akan datang (DEWI, 2016, p. 594; Karmadi, 2007). Dilaksanakannya bakti dan pengenalan candi Kalicilik Blitar dimaksudkan untuk memberikan pengetahuan dan mengajak masyarakat sekitar yaitu siswa SD untuk peduli terhadap keberadaan situs sejarah dengan menjaga dan melestarikan situs sejarah yang ada disekitarnya.

\section{Persepsi Masyarakat terhadap Situs Candi Kalicilik}

Posisi Candi Kalicilik terletak berada di sebelah Barat Wilayah Kabupaten Blitar, kurang lebih 13 Kilometer dari lbukota Kabupaten Blitar yang baru, di Kanigoro. Candi ini berada di Desa Candirejo, Kecamatan Ponggok, Kabupaten Blitar (BPCB Jatim, 2016). Candi ini juga merupakan candi yang berada di antara pemukiman warga dan berada di pingir jalan, sehingga tidak terlalu sulit untuk menemukan candi ini. Sebab tatkala melintas jalur alternative Blitar- Kediri lewat Ponggok, tepatnya di Desa Bacem, ada penanda yang menunjukkan arah keberadaaan candi ini. Tanda tersebut berada di sebelah timur jalan, atau kalau dari Blitar berada di kanan jalan. Dari jalan utama lurus ke timur sekitar $5 \mathrm{~km}$ dan candi berada di sebelah utara jalan.

Sehingga dapat dikatakan masyarakat sekitar Candi Kalicilik ini atau khususnya masyarakat yang berada di desa Candirejo khususnya yang beragama Hindu sudah mengenal dan mengetahui akan Situs Candi Kali cilik yang merupakan peninggalan dari masa kerajaan Majapahit. Menurut bapak Mariyad pun selaku pihak penjaga situs Candi Kalicilik ini mengatakan bahwa masih adanya penggunaan atau dimanfaatkannya Candi Kalicilik dalam pemujaan atau doa bersama di hari khusus atau tertentu umat hindu, individu atau organisasi masyarakat yang mungkin jika rutin dilakukan yakni sebanyak 3 kali dalam setahun. Hal ini pun didukung oleh (beritamadani.co.id, 2016) yang menuliskan bahwa di malam hari diatas jam 11 malam sering dimanfaatkan oleh kaum spiritualis untuk tempat olah spiritual atau doa bersama yang dilakukan oleh Paguyuban Macapat Blitar Kawentar-Kiblat Papat Lima Pancer. Dan menutup acaranya selalu dengan olah karsa dan rasa diiringi doa tembang macapat untuk menambah khidmatnya proses penyucian jiwa menuju penyatuandiri dengan Dzat Maha Suci, sehingga tercapai kondisi manunggal jati menuju RahayuMulya Kang Tinata.

Namun bapak Mariyadi juga mengatakan bahwa dahulu di sekitar candi Kalicilik terdapat banyak sekali arca Agastya namun sekarang tidak tersisa sama sekali karena dicuri oleh masyarakat sekitar maupun masyarakat luar dan sekarang warga di pemukiman situs Candi Kalicilikpun kebanyakan sudah bergama Islam. Oleh karena itu, diperlukannya pengenalan situs candi Kalicilik sejak dini kepada adik-adik siswa-siswi SD Candirejo 01 yang letaknya hanya 400m dari situs dan rumah merekapun tidak jauh dari situs. Peneliti memiliki tujuan agar mereka mengerti akan pentingnya situs Candi Kalicilik dan turut melestarikan, menjaga dan tidak merusak akan warisan budaya tersebut. Selain itu, jumlah pengunjung di Situs Candi Kalicilik bisa dihitung dengan hitungan jari, hanya orang-orang tertentu yang berkunjung ke candi ini selain umat hindu yang ingin melakuakn doa. Seperti; mahasiswa-mahasiswa yang ingin melakukan penelitian untuk tugas kuliah atau skripsi, pasangan pre-wedding yang menggunakan konsep background candi, siswa-siswi dari sekolah sekitar yang diajak gurunya. Sebab sepinya Situs Candi Kalicilik, karena di dalam atau sekitar situs tidak ada fasilitas pendukung sebagai objek pariwisata.hanya pos penjagaan dan pagaar pengaman agar keberadaan candi ini tidak rusak dan hilang karena ulah orang yang tidak bertanggung jawab. Sudah seharusnya objek wisata edukasi yang berada di pinggiran juga diperkenalkan kepada masyarakat luas melalui agenda pariwisata yang bisa diadakan Pemkab Blitar (situsbudaya.id, 2017) 


\section{Implementasi kegiatan bakti dan pengenalan candi Kalicilik}

Bakti dan pengenalan situs candi Kalicilik dilakukan dua kali yaitu pada hari Jumat tanggal 14 Maret dan 22 Maret 2018. Kegiatan di hari pertama adalah bakti candi. Peneliti tiba di candi Kalicilik pada pukul 08.00 WIB.

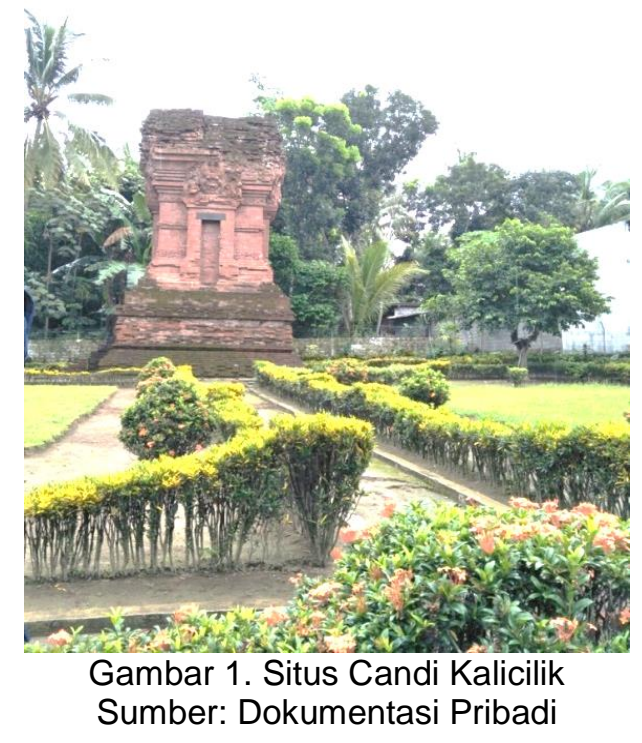

Setelah tiba di lokasi, peneliti membagi tugas, dimana para mahasiswa dibantu dan diarahkan oleh penjaga situs candi untuk memasang papan informasi tentang sejarah candi Kalicilik. Sementara para mahasiswi membersihkan area sekitar candi seperti menyapu halaman candi serta mencabuti rerumputan liar. Untuk pembersihan situs candi, peneliti tidak diperkenankan untuk membersihkan oleh penjaga candi, dengan alasan candi Kalicilik hanya boleh di bersihkan (seperti penyikatan lumut di badan candi), dilakukan oleh penjaga candi yang sudah tahu cara pembersihannya tanpa merusak dan mengikis badan candi. Kegiatan bakti candi dihari pertama berjalan lancer dan berakhir pukul 13.00 WIB.

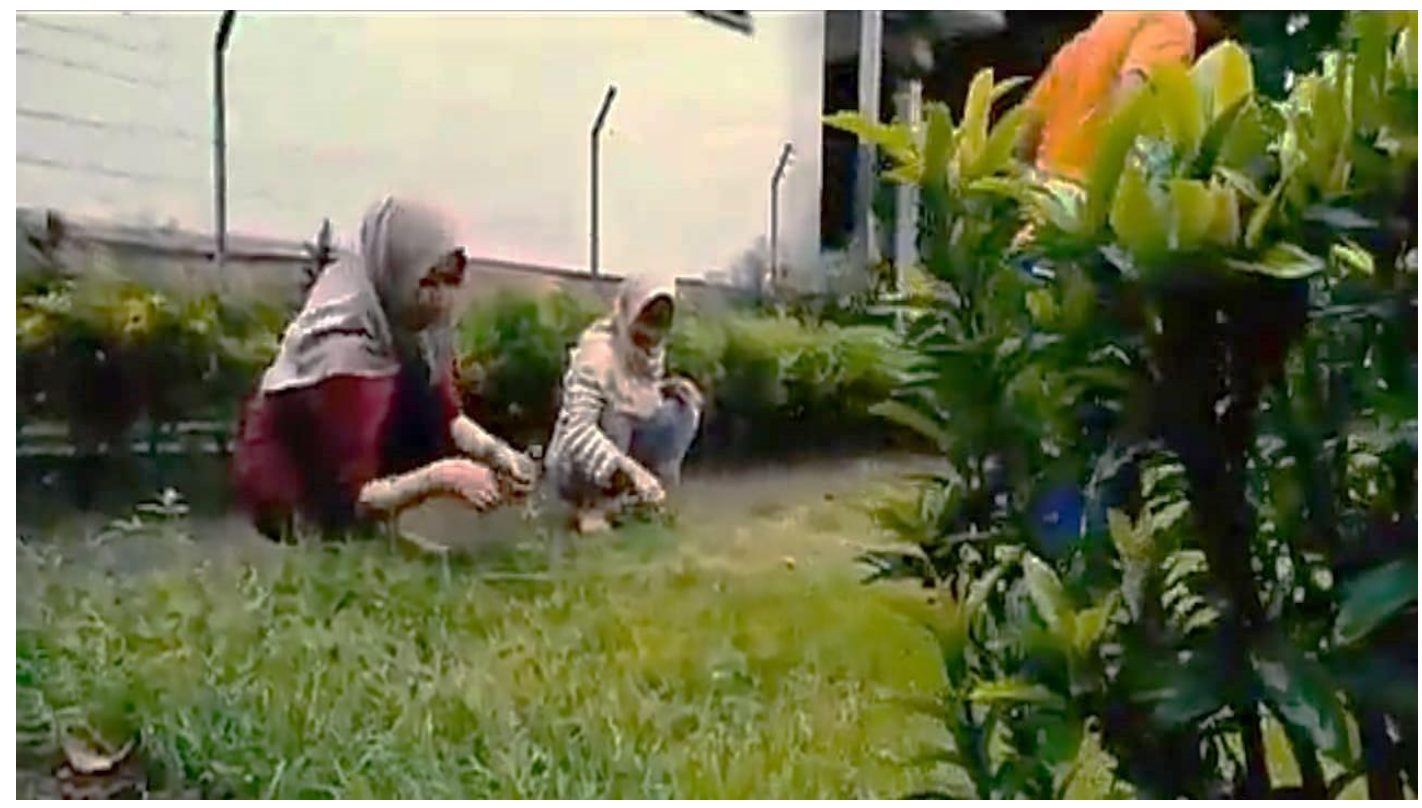

Gambar 2. Membersihkan rumput sekitar candi Sumber: Dokumentasi Pribadi 


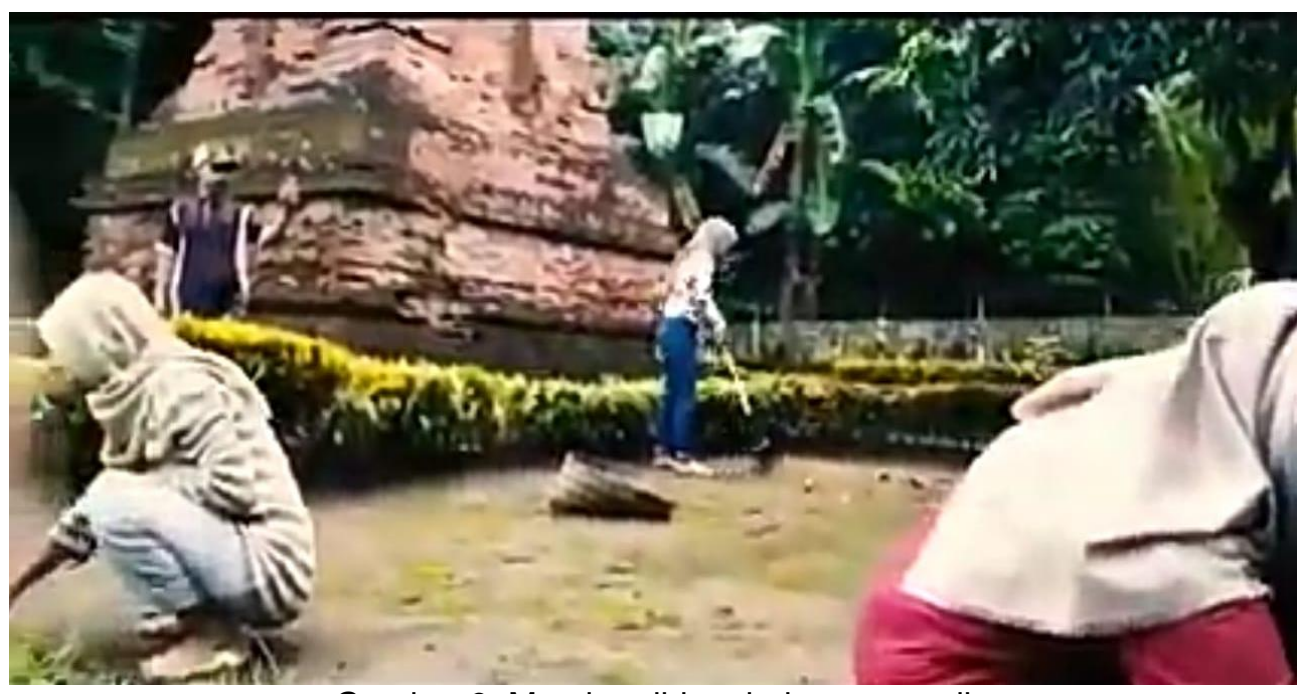

Gambar 3. Membersihkan halaman candi

Sumber: Dokumentasi Pribadi

Kegiatan kedua yaitu pengenalan sejarah candi Kalicilik kepada siswa kelas 4 SD Candirejo 1. Kegiatan dibuka pada pukul 07.30 WIB. Dimana peneliti tiba disekolah tersebut dan diberi kesempatan oleh kepala sekolah SD Candirejo 1 untuk masuk ke dalam kelas untuk menyamapikan maksud kegiatan peneliti serta memberikan arahan kepada para siswa mengenai kegiatan yang akan dilakukan. Setelah selesai menyampaikan maksud dan tujuan kegiatan kepada siswa. Siswa didampingi oleh mahasiswa berjalan menuju ke situs candi.

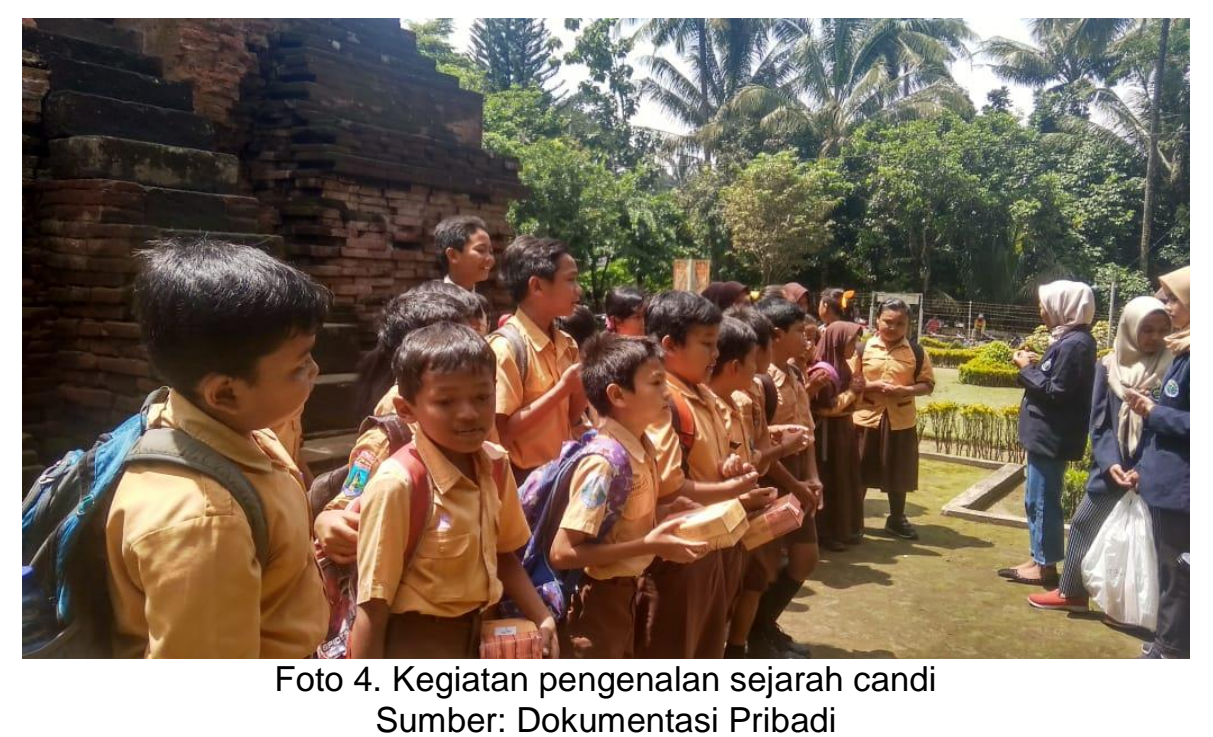

Setelah sampai di candi, selanjutnya peneliti secara bergantian menyampaikan materi yang antara laian berisi sejarah candi Kalicilik, pentingnya mengenal fungsi candi sejak dini, serta pentingnya menjaga dan merawat situs bersejarah. Dalam kegiatan tersebut, siswa sangat antusias bertanya tentang sejarah candi. Kegiatan selanjunya diadakan sesi tanya jawab dimana siswa yang berhasil menjawab pertanyaan akan mendapatkan hadiah berupa buku tulis dan pena. Banyak siswa yang berhasil menjawab dan ada pula siswa yang mendapat hukuman bernyanyi lagu wajib ketika tidak bisa menjawab saat diberi pertanyaan. Kegiatan diakhiri dengan pembagian dan minuman. Tepat pukul 10.30 WIB kegiatan diakhiri dan siswa dikembalikan menuju sekolah.

Kendala yang dihadapi dari kegiatan bakti dan pengenalan situs candi Kalicilik kepada siswa SD Candirejo 1 Ponggok Blitar, pada kegiatan pertama dan kedua, adalah pada hari pertama pemasangan papan informasi sejarah candi pada situs candi, dimana peneliti belum selesai mengurusi surat perijinan yang harus dikirim ke Balai Pelestarian Cagar Budaya Jawa Timur untuk 
pengoreksian isi papan informasi, yang mengakibatkan bila isi papan informasi telah dikoreksi dan mengalami revisi, maka papan informasi harus diganti dan pasang dengan papan informasi yang telah direvisi. Pada kegiatan kedua yaitu pengenalan situs candi kepada siswa, peneliti tidak menemukan kendala atau hambatan dari awal hingga kegiatan berakhir.

\section{Hasil capaian yang didapat}

Keberhasilan kegiatan pembelajaran dapat diukur melalui evaluasi. Kegiatan bakti dan pengenalan candi ini merupakan serangkaian kegiatan pembelajaran oleh karena itu perlu dialakukan evaluasi (Arifin, 2009; Suryanto, 2014). Dalam kegiatan bakti dan pengenalan candi ini kelompok melakukan evaluasi dengan mengajak siswa kelas empat SD Candirejo 1 ke lokasi situs candi Kalicilik di hari selanjutnya setelah kelompok melakukan bakti candi. Dalam kegiatan ini siswa SD candirejo 1 diajak melihat candi Kalicilik lalu dijelaskan secara bergantian oleh setiap masing masing anggota kelompok. siswa kelas 4 SD candirejo 1 sangat antusias dalam mengikuti setiap rangkaian acara dan memperhatikan penjelasan dari kelompok. setelah selesai menjelaskan kelompok membuat game dengan memberikan pertanyaan seputar penjelasan situs candi Kalicilik dan yang bisa menjawab akan diberikan hadiah. Banyak siswa yang bisa menjawab pertanyaan-pertanyaan tersebut dan hampir semua siswa paham dengan materi yang dijelaskan oleh kelompok.

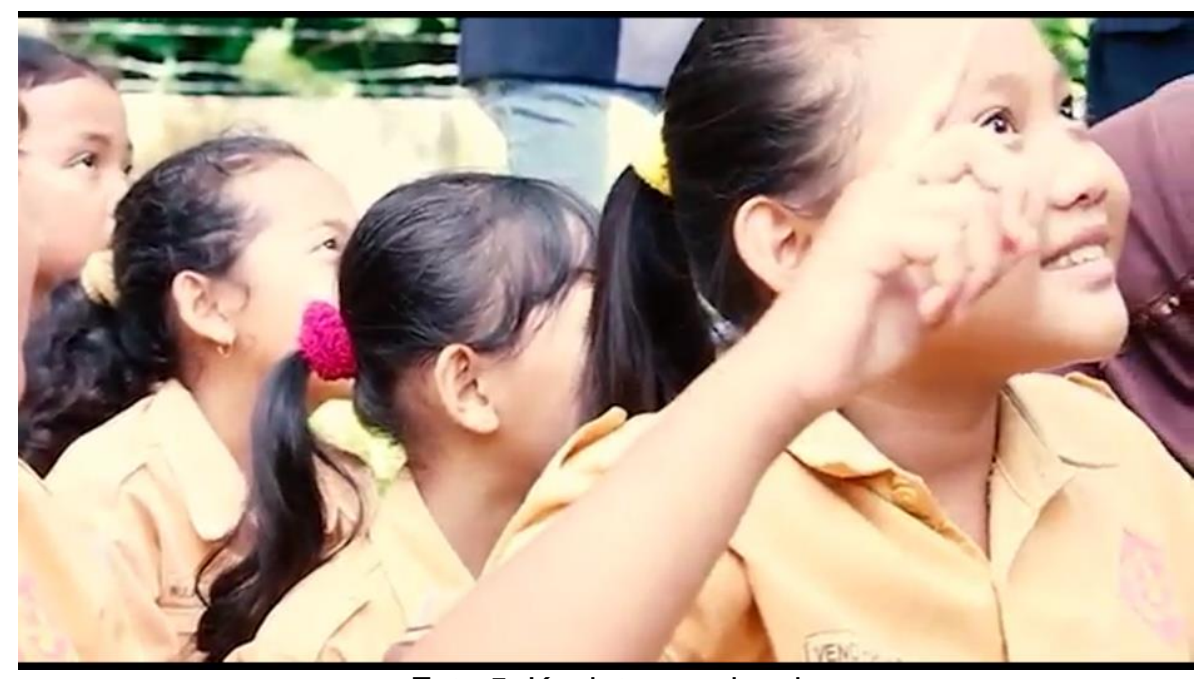

Foto 5. Kegiatan evaluasi

Sumber: Dokumentasi Pribadi

siswa juga terlihat senang bercanda dan bermain dengan kelompok kami di candi bahkan siswa sd canirejo 1 tersebut tidak mau diajak pulang. Walaupun jarak situs candi Kalicilik dekat dengan sd candirejo 1 tetapi mereka hanya diajak 1 kali oleh gurunya ke candi tersebut yaitu pada saat mereka kelas satu sd. Siswa kelas 4 sd canidirejo 1 tersebut mengatakan bahwa mereka senang diajak ke candi Kalicilik dan akan ikut menjaga candi dengan tidak buang sampah sembarangan ketika datang ke candi. Bukan hanya memberikan materi seputar bagian-bagian candi dan sejarahnya kami juga megajarkan siswa-siswa tersebut untuk menjaga kebersihan candi.

Petugas candi Kalicilik mengatakan senang dengan kedatangan kami yang mau melakukan bakti candi dan memperkenalkan kepada generasi muda. Selain itu kelompok kami juga mendapat ilmu yang sangat bermanfaat dari kegiatan baktis dan pengenalan candi terebut. Seperti mengetahui bagaimana awal mula ditemukannya situs candi Kalicilik tersebut, tata cara pengelolaan candi yang benar dan juga bagaimana tata cara mengurus perizinan melakukan kegitaan di situs-situs sejarah. Dan masih banyak lagi pengalaman-pengalaman yang kami dapat dalam kegiatan baktis dan pengenalan candi di situs candi Kalicilik tersebut. 


\section{KESIMPULAN}

Kegiatan bakti dan pengenalan situs candi Kalicilik kepada siswa SD 1 Candirejo 1 Ponggok Blitar secara keseluruhan terlaksana dengan baik sesuai dengan tujuan. Hal ini dapat dilihat dari kelancaran kegiatan, siswa antusias untuk mengikuti pengenalan situs candi Kalicilik dari awal hingga diakhir kegiatan. Bakti dan pengenalan candi Kalicilik dilakukan dengan membersihkan lingkungan sekitar candi dilanjutkan dengan pengenalan candi kepada siswa SD candirejo 1 Ponggok Blitar. Sebagian besar masyarakat sekitar khususnya siswa SD 1 Candirejo sudah mengenal peninggalan masa Majapahit tersebut, akan tetapi ada beberapa siswa yang belum mengenal situs candi Kalicilik. Pengenalan situs candi disambut dengan baik, siswa SD 1 Candirejo sangat tertarik, dan memperhatikan penjelasan yang diberikan. Setelah dijelaskan secara singkat mengenai sejarah Candi Kalicilik siswa bisa menjawab pertanyaan yang diberikan dengan benar, mereka sangat antusias mengikuti kegiatan. Saran dan rekomendasi untuk kedepanya khususnya kepada pihakpihak sekolah yang berada disekitaran situs candi untuk menjadikanya sebagi sumber belajar. Ada suatu kegiatan rutin dalam siklus tertentu untuk mengajak peserta didiknya mengunjungi situs sejarah di daerahnya. Hal ini efektif untuk mengenalkan anak-anak terhadap keberadaan situs sejarah dan pentingnya menjaga serta merawatnya.

\section{UCAPAN TERIMA KASIH}

Tim pengabdian masyarakat mengucapkan banyak terimakasih pada Bapak Mariyad selaku pihak penjaga situs candi Kalicilik yang telah membantu dan mengarahkan tim dalam kegiatan bakti candi. Selain itu, taklupa mengucapakan banyak terimakasih kepada Kepala Sekolah SD Candirejo 1 dan Wali Kelas IV SD Candirejo 1 yang telah memberikan izin untuk mengenalkan sejarah situs candi Kalicilik kepada siswa-siswi kelas IV SD Candirejo 1.

\section{DAFTAR PUSTAKA}

Agustin, D. S. Y. 2011. Penurunan Rasa Cinta Budaya dan Nasionalisme Generasi Muda Akibat Globalisasi. Jurnal Sosial Humaniora, 4(2), 177-185.

Arafah, B. 2003. Warisan Budaya, Pelestarian dan Pemanfaatannya. Artikel. Fakultas IImu Budaya. Universitas Hasanuddin (UNHAS).

Arifin, Z. 2009. Evaluasi pembelajaran (Vol. 8). Bandung: Remaja Rosdakarya.

beritamadani.co.id. 2016, May 24. Macapat Kiblat Papat Lima Pancer Di Candi Kali Cilik Blitar. Retrieved May 16, 2019, from Beritamadani.co.id website:

https://beritamadani.co.id/2016/05/24/macapat-kiblat-papat-lima-pancer-di-candi-kali-cilikblitar/

BPCB Jatim. 2016, November 9. Sejarah Candi Kalicilik. Retrieved May 16, 2019, from Balai

Pelestarian Cagar Budaya Jawa Timur website:

https://kebudayaan.kemdikbud.go.id/bpcbjatim/sejarah-candi-kalicilik/

Campbell, C. 2002. Ngapain ke Candi? ACICIS/Universitas Muhammadiyah Malang.

Chowanda, A., \& Prasetio, Y. L. 2012. Perancangan Game Edukasi Bertemakan Sejarah Indonesia. Proceedings SEMANTICS, 151-155.

DEWI, F. L. 2016. BANGUNAN CAGAR BUDAYA PERPUSTAKAAN BANK INDONESIA SURABAYA (Studi Deskriptif tentang Upaya Pelestarian Bangunan Cagar Budaya Perpustakaan Bank Indonesia Surabaya) (PhD Thesis). Universitas Airlangga.

Karmadi, A. D. 2007. Budaya lokal sebagai warisan budaya dan upaya pelestariannya. Makalah Disampaikan Pada Dialog Budaya Daerah Jawa Tengah Yang Diselenggarakan Oleh Balai Pelestarian Sejarah Dan Nilai Tradisional Yogyakarta Bekerjasama Dengan Dinas Pendidikan Dan Kebudayaan Propinsi Jawa Tengah, Di Semarang, 8-9.

Maslahah, W., \& Rofiah, L. 2019. Pengembangan Bahan Ajar (Modul) Sejarah Indonesia Berbasis Candi-Candi Di Blitar Untuk Meningkatkan Kesadaran Sejarah. AGASTYA: JURNAL SEJARAH DAN PEMBELAJARANNYA, 9(1), 32-43.

Mikkelsen, B. 2011. Metode penelitian partisipatoris dan upaya pemberdayaan: Panduan bagi praktisi lapangan. Yayasan Pustaka Obor Indonesia. 
Bakti dan Pengenalan Situs Candi Kalicilik pada Siswa SD 1 Candirejo Ponggok Blitar

Nafi'ah, U., Utami, I. W. P., Sulistyo, W. D., Mahmud, J. A., \& Minarti, M. 2019. PERANCANGAN MOTIF BATIK DENGAN INSPIRASI RELIEF ORNAMENTASI CANDI KIDAL SEBAGAI PENGEMBANGAN CORAK BATIK DESA KIDAL. Jurnal Praksis Dan Dedikasi Sosial, 1(2), 110-116.

Sedyawati, E., Santiko, H., Djafar, H., Maulana, R., Ramelan, W. D. S., \& Ashari, C. 2013. Candi Indonesia: Seri Jawa: Indonesian-English. Direktorat Jenderal Kebudayaan.

situsbudaya.id. 2017, September 11. Situs Candi Kalicilik Situs Peninggalan Desa Candirejo. Retrieved May 16, 2019, from Informasi Situs Budaya Indonesia website: https://situsbudaya.id/situs-candi-kalicilik/

Sulistyo, W. D. 2019. MENGGUGAH SENSITIVITAS SOSIAL MAHASISWA MELALUI IMPLEMENTASI PRAKSIS SOSIAL. Jurnal Sosiologi Pendidikan Humanis, 4(1), 38-46.

Suryanto, A. 2014. Evaluasi Pembelajaran di SD.

Vubo, E. Y. 2003. Levels of Historical Awareness. Cahiers d'études Africaines, (3), 591-628.

Wendoris, T. 2008. Mengenal Candi-candi Nusantara. Pustaka Widyatama.

Wibowo, A. B. 2014. Strategi Pelestarian Benda/Situs Cagar Budaya Berbasis Masyarakat. Jurnal Konservasi Cagar Budaya Borobudur, 8(1), 58-71. 